\title{
Factors of Gender Inequality and Development among Selected Low Human Development Countries in Sub-Saharan Africa
}

\author{
*Azuh Dominic ${ }^{1}$, Lanre Amodu ${ }^{2}$, Akunna Ebere Azuh ${ }^{3}$, Oresanya Toluwalope ${ }^{4}$, \\ Matthew A. Oluwatoyin ${ }^{5}$ \\ ${ }^{I}$ Department of Demography and Social statistics, \\ College of Business \& Social Sciences, Covenant University, Ota, Ogun State, Nigeria \\ *Corresponding Author \\ ${ }^{2,4}$ Department of Mass Communication \\ College of Business \& Social Sciences, Covenant University, Ota, Ogun State, Nigeria \\ ${ }^{3}$ Department of Estate Management \\ College of Science and TechnologyCovenant University Ota, Ogun State, Nigeria. \\ ${ }^{5}$ Department of Economics \& Development Studies, \\ College of Business \& Social Sciences, Covenant University, Ota, Ogun State, Nigeria
}

\begin{abstract}
Gender inequality and poor women empowerment retard improvement in living standards of women and act as a clog in their contributions to governance and economic development. Gender inequality lower quality of life and culminates in limited productivity, hinder economic efficiency and growth. For over three decades, gender issues have been at the front burner of international summits. In spite of much progress in recent times, gender inequalities remain pervasive in many dimensions of life in various regions around the world particularly in sub-Saharan Africa (SSA). Treatment of women is yet to be fairer and related policies can be more effective to improve the status of women. No-doubt studies have been carried out on gender inequality, but less emphasis has been raveled with respect to hindrances and implications of gender inequality. Hence, understanding the nature of gender inequality will not only promote sound awareness among African countries, but also ignite government efforts as well as NGOs toward effective interventions for reduction of gender inequality especially in the economic and political realms where women are made worse off by the sociocultural milieu. The methodological approach to this paper was based on reviews of published multiple documents to draw up statistical profile of the situation of women in selected countries of low human Development index in SSA to show the existence of gender inequality. The paper found among all the 12 low human development countries and SSA region examined that gender indicators such as human development index, expected years of schooling, mean years of schooling, estimated gross national per capita, share of seats in parliament, population with at least secondary education and labor-force participation rate are all in favor of men. The paper concludes with recommendations to narrow the gender gaps.
\end{abstract}

Keywords: Economic development, gender inequality, governance, women empowerment, socio-cultural

\section{INTRODUCTION}

Gender inequality and poor women empowerment retard improvement in living standards of women and act as a clog in their contributions to governance and economic development. In other words, gender equality empowers the transformation of women to access education, health, micro finance credit and recognition among other productive resources. Gender inequality lowers quality of life and culminates in limited productivity, hinders economic efficiency and growth. The benchmark for a successful society is the level of gender equality which reflects on the extent of women's rights and empowerment in that society. Men and women have roles to play in societal development, yet women all over the world are grossly marginalized. According to Singh and colleagues, women comprise half of human resources and they have been identified as key agent of sustainable development [1]. The United Nations Development Programme's human development report observed that there is a continual discrepancy in education and employment opportunities in terms of gender related issues in sub- Saharan Africa [2]. Furthermore the INSTRAW Report, noted that out of the 1 billion people living in poverty around the world, greater percentage of them is women [3].Gender comprises a range of differences between men and women, extending from the biological to the social spheres. The biological difference has necessitated differences in gender roles in society and on gender identity, which has been defined as "an individual's self-conception as being male or female, as distinguished from actual biological sex". Specifically, the term gender refers to a socially constructed and socially learned behaviours and expectations associated with females and males. All cultures interpret and elaborate the biological difference 
between women and men into a set of social expectations about what behaviours and activities are appropriate and what rights, resources, and power women and men possess. But like race, ethnicity, and class, gender is a social category that largely establishes one's life chances. It shapes one's participation in society and in the economy. Therefore, while the term gender refers to men and women, for the purpose of this presentation, gender refers to the condition of women in the African societies. In other words, the term "gender" may influence economic, social and cultural attributes and opportunities associated with being male or female. In almost all societies, women and men differ in their activities and undertakings, regarding access to and control over resources, and participating in decision-making. Gender, being male or female is an important social division characterized by inequality. Gender inequality is a social construct that has societal backing leading to gender disparity between the two sexes, with respect to functions, rights to resources, responsibility and power/positions. It may relate to gender discrimination/unequal treatment against the female counterparts or unfair treatment given to female gender with respect to the male in numerous spheres of life. In a maternal mortality study in South West Nigeria, Azuh and his Colleagues observed that men had upper hand in virtually all decisions more than their wives including health issues such as pregnancy and child birth [4].African women face high levels of inequality and discrimination that have an impact on their socio-economic growth leading to their low contributions towards sustainable development of African continent. They are not involved in household decisions about spending their personal earned income [5], [6]. The United Nations noted also that inequalities between women and men persist in many aspects of life in most countries [7]. To join their counterparts in developed countries in terms of gender equality, African countries need to address structural barriers that discriminate against women and girls in accessing education, employment and income as well as cultural impediments/restrictions on the rights of women inheritance that hold back progress on the gender front in Africa today [ 8 ]. For instance, Fasuba asserts that Nigerian women, like in other developing countries of the world, suffer from undue discrimination, marginalization and exploitation by the men folk through the implementation of their culture of religious and traditional beliefs which placed men as super human beings [9]. A notable scholar, Also Yomi raised another challenge which he described as the "patrilineal system of descent" in which generations are identified through male offspring. The responsibility for the preservation and continuity of the "family tree" rests on the male children and special recognition are accorded them in the preparation for their adult roles [10]. Despite UN Convention on the Elimination of All forms of Discrimination Against Women 1979 (which calls for the equal rights for man and women in bringing and education of children and in general for equality of rights and duties in marriage and divorce), International Conference on Population and Development Cairo 1994 (which equally addressed the need for broader policies in population control through responsible economic development, education and empowerment of women and quality health care including family planning services), The Beijing Platform for Action, adopted at the Fourth World Conference on Women in 1995 (which insists that women be fully integrated into the system of development around the world), Maputo Protocol 2011 (which asserts the right of women by ensuring their social and political equality with men and control their reproductive health), (Millennium Development Goal-3 (which provided direction for governments focusing on education, employment and political participation and more recently), Sustainable Development Goal-5 (which calls on the international community to "achieve gender equality and empower all women and girls"), yet gender inequality still persists in Africa leading to gaps between males and females in various life affecting indicators such as economic constraint, low political participation and empowerment, low educational attainment and poor health, cultural and religious restrictions and injunctions, high burden of family responsibilities and poor exposure than their male counter parts.Being a woman or a man influences people's perspectives and their social expectations. Compared with men, women have very limited opportunities in most spheres of economic and social activities [11], [12]. Similarly, World Bank Report (cited in National Population Commission report [ 13 ], states that failure to include women in all aspects of life is responsible for the continued underdevelopment of countries in sub-Saharan Africa as it associated with poverty, slower economic growth, weaker governance and lower quality of life with gender disparities. At the national level, several policies exist towards bridging the gap on gender equality and development, yet they have not yielded the expected result. Women are not accorded equal status with men in practically all fields of human endeavour. Accelerating gender equality will not only raise the status of women but also empower them and make African women less dependent on their male counterparts. It has been reported that gender inequality is costing sub-Saharan Africa an average \$US95 billion a year thereby endangering the continent's efforts for inclusive human development and economic growth [14]. The report further observed that a 1 percent increase in gender inequality reduces a country's human development index by 0.75 percent. The collection of gender-differentiated information on the social, environmental, technical and economic aspects of development will render planning for development more efficient and egalitarian.The concept of development has been viewed from different angles; social, economic, political and cultural. Development. .According to Akintayo and colleague, it is a process of economic, social, political and cultural change engineered in a given society by the efforts of all stakeholders both internal and external [15]. 
Development is a multidimensional, diverse and a presumably ameliorative upwards movement of the entire socio- economic system, giving a differential emphasis to improving appropriate sectors, ultimately in an increase in levels of income, improvement in quality of life and stabilization of population. Development is a process of improving the quality of all human lives, raising of people's living standards and creation of conditions conducive to the growth of people's self esteem through establishment of social, political and economic systems and institutions[ 16 ], [17 ] .Furthermore, Todaro and Smith stated the three core values of development, which are sustenance-the ability to meet basic needs, self-esteem and freedom from servitude; the three objectives of Development are - to increase the availability and widen the distribution of basic lifesustaining goods such as food, shelter, health, and protection; raise levels of living, including, in addition to higher incomes, the provision of more jobs, better education, and greater attention to cultural and human values, all of which will serve not only to enhance material well-being but also to generate greater individual and national self-esteem; and expand the range of economic and social choices available to individual and nations by freeing them from servitude and dependence. Development is measured through human development indicators such as infant mortality rate, live expectancy at birth, literacy rate, and gross domestic product, among others. Therefore, from the foregoing, the objectives of the paper are to examine inequality between males and females among selected low human development index (LHDI) countries in SSA and proffer solutions to ameliorate the surge.

\section{METHODS AND THEORIZING GENDER INEQUALITY}

The methodological approach to this paper was based on reviews of published multiple documents to draw up statistical profile of the situation of women in selected LHDI countries in SSA to show the existence of gender inequality. Women suffer from all forms of disadvantages or denials which affect their health, independence, productive resources and contribution to development processes. In order to comprehend gender roles very well, there is need to examine some theoretical framework related to gender inequality. There are several frameworks on gender inequality roles due to the diversity of the concept but four most related to the present paper were described. The functionalist perspective sees society as a complex system and suggests that gender inequalities exist to maximize social efficiency. This approach looks at society through a macro-level orientation and broadly focuses on the social structures that shape society as a whole. The functionalist perspective of gender inequality was most robustly articulated in the 1940s and1950s, and largely developed by Talcott Parsons' model of the nuclear family. This theory suggests that gender inequalities exist as an efficient way to create a division of labour, or as a social system in which particular segments are clearly responsible for certain, respective acts of labour which works to maximize resources and efficiency. A structural functionalist view of gender inequality applies the division of labour to view predefined gender role as complementary; women take care of the home while men provide for the family. Thus gender, like other social institutions contributes to the stability of society as a whole. According to Ritzer, functionalism focuses on the structures of society and their functional significance (positive or negative consequences) for other structures [18]. The primary concern of functionalism is the large-scale social structures and institutions of society, their interrelationships, and their constraining effects on actors. The liberal feminism theory, which is based or anchored on the ideals of equality and liberty, has bearing on gender relations. The liberal conception of equality was based on the belief that all humans had the potential to be rational and that any inequality has to be justified in rational terms. The theory argued that the reason women appear to be intellectually inferior was due to their inferior education and therefore were a result of inequality rather than a justification for it. Liberal feminists are women's subordination as resulting from general norms, rather than from biological sex and aim to change these norms. Liberal feminists focus on equal opportunity for men and women in all spheres of endeavour [19]. Gender and Development theory (GAD) emerged in the late 1980s as a pre-Beijing perspective in response to the failure of the Women in Development (WID) Approach to change the lives of women and influence broader development agenda. WID focused on women in isolation ignoring unequal gender relation in various social and economic settings [ 20 ], [ 21 ] GAD deals with social, economic, political and cultural forces that determine how men and women participate in, benefit from, and control project resources and activities differently. Hence the approach shifts the focus from women as a group to the socially determined relations between women and men (UN INSTRAW Glossary-Related Terms and Concepts). The approach 'seeks to ensure that all decisions concerning development be reached through the local equitable participation of men and women in the development processes [22]. 
Table 1 HDI Indicators of Selected SSA Countries in Low Development Index

\begin{tabular}{|c|c|c|c|c|c|}
\hline $\begin{array}{l}\mathbf{S} / \\
\mathbf{N}\end{array}$ & Region/Country & $\begin{array}{c}\text { Life } \\
\text { expectancy } \\
\text { at birth }\end{array}$ & $\begin{array}{c}\text { Expected } \\
\text { years of } \\
\text { schooling }\end{array}$ & $\begin{array}{l}\text { Mean years } \\
\text { of schooling }\end{array}$ & $\begin{array}{c}\text { Population } \\
\text { with at } \\
\text { least some } \\
\text { secondary } \\
\text { education }\end{array}$ \\
\hline & & $\begin{array}{l}\mathbf{F} \\
\mathbf{M}\end{array}$ & $\begin{array}{l}\mathbf{F} \\
\mathbf{M}\end{array}$ & $\begin{array}{l}\mathbf{F} \\
\mathbf{M}\end{array}$ & $\begin{array}{ll}\mathbf{F} & \mathbf{M}\end{array}$ \\
\hline 1. & Sub Saharan Africa & $\begin{array}{l}59.7 \\
57.1\end{array}$ & $\begin{array}{c}9.1 \\
10.3\end{array}$ & $\begin{array}{l}4.2 \\
6.0\end{array}$ & $\begin{array}{l}22.1 \\
31.5\end{array}$ \\
\hline 2. & Burkina Faso & $\begin{array}{l}59.9 \\
57.3 \\
\end{array}$ & $\begin{array}{ll}7.4 & 8.1\end{array}$ & $\begin{array}{l}1.0 \\
1.9 \\
\end{array}$ & $\begin{array}{l}0.9 \\
3.2\end{array}$ \\
\hline 3. & Cameroon & $\begin{array}{l}56.7 \\
54.4 \\
\end{array}$ & $\begin{array}{c}9.5 \\
11.2 \\
\end{array}$ & $\begin{array}{l}5.3 \\
6.7 \\
\end{array}$ & $\begin{array}{l}21.3 \\
34.9\end{array}$ \\
\hline 4. & Congo (DR of the) & $\begin{array}{l}60.1 \\
57.2\end{array}$ & $\begin{array}{c}8.6 \\
10.8\end{array}$ & $\begin{array}{l}4.5 \\
7.7\end{array}$ & $\begin{array}{l}12.8 \\
32.4\end{array}$ \\
\hline 5. & Ethiopia & $\begin{array}{l}66.0 \\
62.2\end{array}$ & $\begin{array}{l}8.0 \\
9.0\end{array}$ & $\begin{array}{l}1.4 \\
3.6 \\
\end{array}$ & $\begin{array}{c}7.8 \\
18.2\end{array}$ \\
\hline 6. & Kenya & $\begin{array}{l}63.4 \\
59.9 \\
\end{array}$ & $\begin{array}{l}10.7 \\
11.3\end{array}$ & 5.9 & $\begin{array}{l}25.3 \\
31.4 \\
\end{array}$ \\
\hline 7. & Lesotho & $\begin{array}{l}49.8 \\
49.6\end{array}$ & $\begin{array}{l}11.7 \\
10.6\end{array}$ & 6.5 & $\begin{array}{l}21.9 \\
19.0\end{array}$ \\
\hline 8. & Malawi & $\begin{array}{l}63.7 \\
61.7 \\
\end{array}$ & $10.8 \quad 10.7$ & 3.4 & $\begin{array}{l}11.1 \\
21.6 \\
\end{array}$ \\
\hline 9. & Mali & $\begin{array}{l}57.8 \\
58.2 \\
\end{array}$ & $\begin{array}{ll}7.5 & 9.3\end{array}$ & 1.5 & $\begin{array}{c}7.7 \\
15.1 \\
\end{array}$ \\
\hline 10. & Nigeria & $\begin{array}{l}53.1 \\
52.4\end{array}$ & $\begin{array}{ll}8.2 & 9.8\end{array}$ & 4.9 & - \\
\hline 11. & Rwanda & $\begin{array}{l}67.0 \\
61.1 \\
\end{array}$ & $\begin{array}{l}10.4 \\
10.2 \\
\end{array}$ & 4.3 & 8.8 \\
\hline 12. & S enegal & $\begin{array}{r}68.3 \\
64.4 \\
\end{array}$ & $\begin{array}{l}7.8 \\
8.1 \\
\end{array}$ & $\begin{array}{l}1.8 \\
3.2 \\
\end{array}$ & $\begin{array}{c}7.2 \\
15.4 \\
\end{array}$ \\
\hline 13. & Swaziland & $\begin{array}{l}48.2 \\
49.6\end{array}$ & $\begin{array}{l}10.9 \\
11.8 \\
\end{array}$ & $\begin{array}{l}7.4 \\
6.8 \\
\end{array}$ & $\begin{array}{l}21.9 \\
29.0 \\
\end{array}$ \\
\hline
\end{tabular}

Source: UNDPHDR 2015

Table 2 HDI Indicators of Selected SSA Countries in Low Development Index

\begin{tabular}{|c|c|c|c|c|c|}
\hline $\begin{array}{l}\mathbf{S} / \\
\mathbf{N}\end{array}$ & Region/Country & $\begin{array}{l}\text { Human } \\
\text { Developm } \\
\text { ent Index } \\
\text { (HDI) } \\
\text { F } \\
\text { M } \\
\end{array}$ & $\begin{array}{l}\text { Estimated } \\
\text { GNI per } \\
\text { capita } \\
\text { F } \\
\text { M }\end{array}$ & $\begin{array}{c}\text { Share of } \\
\text { seats in } \\
\text { parliamen } \\
t \\
\text { (Female) }\end{array}$ & $\begin{array}{l}\text { Labour } \\
\text { force } \\
\text { participati } \\
\text { on rate } \\
\text { F } \\
\text { M }\end{array}$ \\
\hline 1. & Sub Saharan Africa & $\begin{array}{l}0.48 \\
0.55\end{array}$ & $\begin{array}{l}2,626 \\
4,148\end{array}$ & 22.5 & $\begin{array}{c}65.4 \\
76.6\end{array}$ \\
\hline 2. & Burkina Faso & $\begin{array}{l}0.38 \\
0.43\end{array}$ & $\begin{array}{l}1,325 \\
1,859\end{array}$ & 13.3 & $\begin{array}{c}77.1 \\
90.0\end{array}$ \\
\hline 3. & Cameroon & $\begin{array}{l}0.48 \\
0.54\end{array}$ & $\begin{array}{c}2,266 \\
3,341\end{array}$ & 27.1 & $\begin{array}{c}63.8 \\
76.5\end{array}$ \\
\hline 4. & Congo (DR of the) & $\begin{array}{l}0.39 \\
0.47\end{array}$ & $\begin{array}{c}597 \\
765\end{array}$ & 8.2 & $\begin{array}{c}70.7 \\
73.2\end{array}$ \\
\hline 5. & Ethiopia & $\begin{array}{l}0.40 \\
0.48\end{array}$ & $\begin{array}{c}1,090 \\
1,765\end{array}$ & 25.5 & $\begin{array}{c}78.2 \\
89.3\end{array}$ \\
\hline 6. & Kenya & $\begin{array}{l}0.53 \\
0.58\end{array}$ & $\begin{array}{c}2,255 \\
3,270\end{array}$ & 20.8 & $\begin{array}{c}62.2 \\
72.4\end{array}$ \\
\hline 7. & Lesotho & $\begin{array}{l}0.48 \\
0.51\end{array}$ & $\begin{array}{c}2,613 \\
4,017\end{array}$ & 26.8 & $\begin{array}{c}59.0 \\
73.5\end{array}$ \\
\hline 8. & Malawi & 0.42 & 679 & 16.7 & 84.6 \\
\hline
\end{tabular}




\begin{tabular}{|c|l|l|l|l|l|}
\hline & & 0.47 & 815 & & 81.5 \\
\hline 9. & Mali & 0.36 & 961 & 9.5 & 50.8 \\
& & 0.47 & 2,195 & & 81.4 \\
\hline 10 & Nigeria & 0.47 & 4,052 & 6.6 & 48.2 \\
. & & 0.56 & 6,585 & & 63.7 \\
\hline 11 & Rwanda & 0.47 & 1,312 & 57.5 & 86.4 \\
. & & 0.49 & 1,612 & & 85.3 \\
\hline 12 & Senegal & 0.44 & 1,657 & 42.7 & 66.0 \\
. & & 0.49 & 2,739 & & 88.0 \\
\hline 13 & Swaziland & 0.49 & 3,894 & 14.7 & 43.9 \\
. & & 0.56 & 7,235 & & 71.6 \\
\hline
\end{tabular}

Source: UNDPHDR 2015

\section{FINDINGS AND DISCUSSION}

Gender inequality is a wedge to development. Tables 1 and 2 examined the inequality based on the following indicators namely life expectancy at birth, expected years of schooling, mean years of schooling, population with at least some secondary education, human resource development index (HDI), estimated GNI per capita, share of seats in parliament and labour force participation rate. Gender inequality exists prominently in the areas of education, labor force, access to productive resources, politics and social status. All of these have implications for female growth and contribution towards development. Despite the fact that women's population constitutes a great proportion yet there exists inequality in terms of education, employment, political participation, access to reproductive resources and social status. In fact, as the inequality increases the loss in human development also increases. Education enhances women's status and expands her employment potentials leading to their economic independence. According to the Human Development Report [ 23] (2015) figures for all selected low human development index countries in SSA examined showed greater disparity between males and females as indicated in table 1 and 2 . The Table 1 showed the existence of gender inequality among all the countries examined including the SSA region. For all the indicators considered, females had lower rates compared to males except for life expectancy at birth where females had advantage over males across all countries though with marginal increase over females in Mali and Swaziland respectively. Nevertheless, with respect to expected years of schooling Lesotho, Malawi and Rwanda females had higher figures than their male counterparts. For mean years of schooling and population with at least some secondary education, female inequality prominently manifested except for few isolated cases as shown in both Table 1 and Fig. 1.

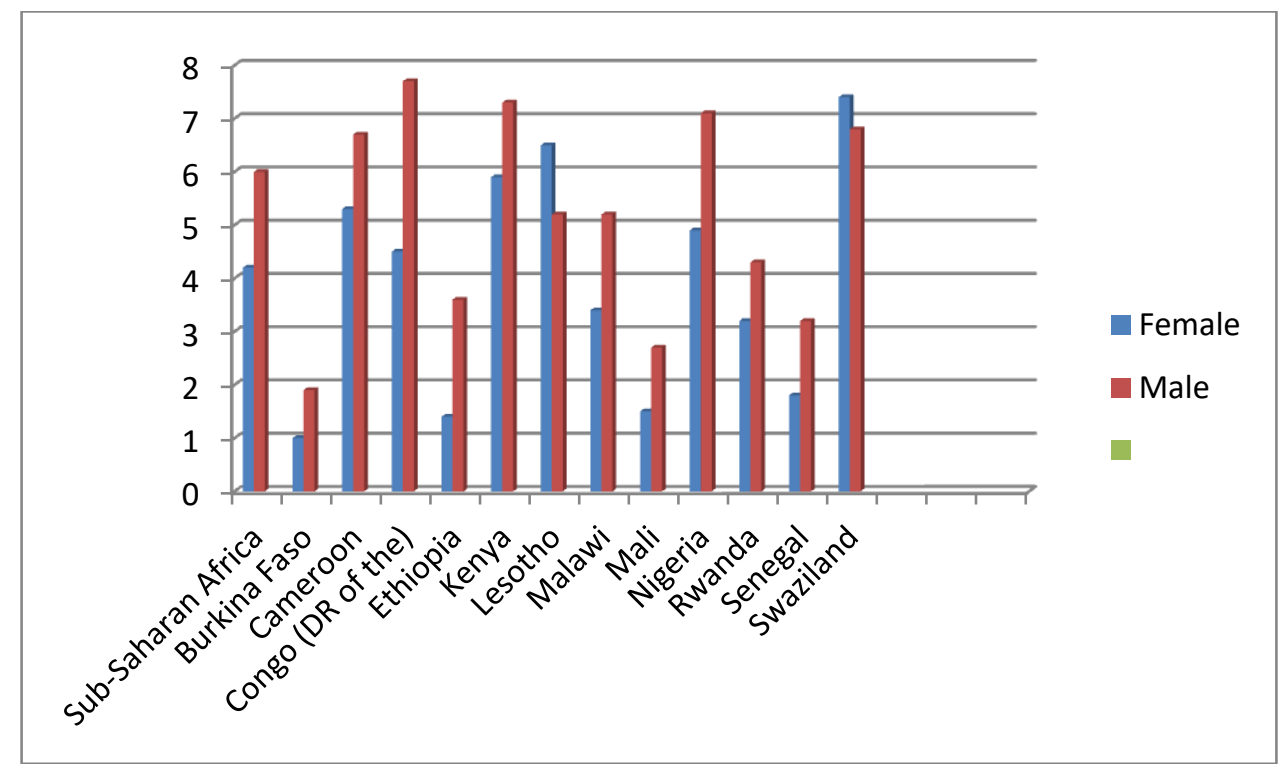

Fig. 1 Mean years of schooling among selected SSA countries in Low Development Index

In Table 2, similar female inequality was noticed on Human Development Index (HDI) among all selected countries. Gross National Income (GNI) per Capita which indicates a measure of standard of living was equally unfavourable to females across all selected countries. Women participation in politics showed the normal male domination with the exception of Rwanda and Senegal where females' share of seats in parliament 
were $57.5 \%$ and $42.7 \%$ respectively as depicted in fig. 1 . The incursion of women in politics and representation in parliament/governance is an important milestone for development in Africa and particularly among SSA. For instance, H.E. Ellen Sirleaf- Johnson, the first elected female head of State in Africa, became President of Liberia as it emerged from conflict in 2005 and is currently serving her second term after re-election in 2011. Joyce Banda became President of Malawi in 2012, and H.E. Catherine Samba-Panza took over the Presidency of the Central African Republic in 2014. In 2015, H.E. Ameenah Gufrib-Fakium became President of Mauritius.

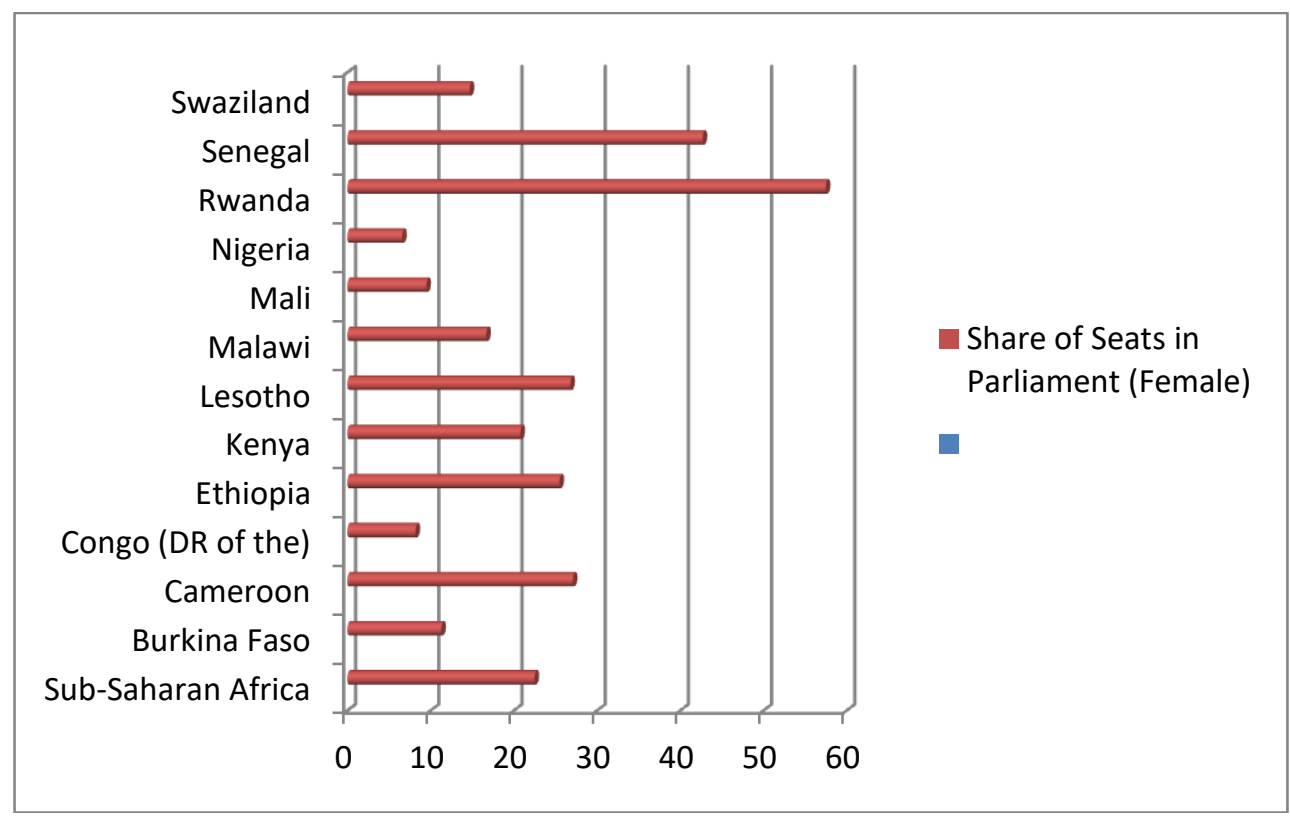

Fig. 2 Share of seats in parliament (Female) among selected SSA countries in Low Development Index

Other women who were not elected nevertheless have also assumed top leadership positions in African states. For instance, the election of H.E. Dr. Nkosazana Dlamini Zuma as the Chairperson of the African Union Commission in 2012 was a landmark in its 50-year existence since no woman had previously led the organization. This emerging trend in women's political participation in Africa has been reflected by the increase in the number of women in parliament. At present, Rwanda is the global leader at 57.5 per cent women parliamentarians, Senegal at 42.7 per cent. However, vast majority of other countries are still crawling behind such as Nigeria (6.6\%), Congo DR (8.2\%), Mali (9.5\%), Burkina Faso (13.3\%), Swaziland (14.7\%) among others as shown in Table 2 and Fig. 2.No doubt, women have become much more visible in African politics, where they are beginning to change the political agenda in their respective countries. Unequal opportunities to work perpetuate socio-economic inequality. Work allows people both males and females to contribute to societal development through productive and satisfying work opportunities. Table 2 showed that women are highly discriminated in labor force except for Malawi and Rwanda even though these advantages were marginal.

\section{CONCLUSION}

Gender inequality/disparities were found to exist in all variable indicators considered among the selected LHDI countries in SSA In many African communities, females are not allowed to be in school. Families preferred to invest in boys' education than in girls. Women were also not allowed to do major economic activity and had less ownership of lands and assets. In fact, in traditional Africa, a married woman is considered as the legal property of her husband. Ideally, a real democratic system should allow voluntary individual participation in politics, without any sentiments about gender, to optimally benefit from the potentials of women in social and political life. This idea negatively impacts on the well-being of women, and the development of their children is also impacted negatively. The inequality observed across all countries encourages subjugation; dependency of females on male folk, killing entrepreneurship zeal thereby orchestrating poor quality of life, denying women their meaningful contributions to household, community and nation's development. The paper recommends public enlightenment particularly for men folk towards socio-economic transformation and "cultural revolution" In addition, educational opportunities should be given to girls and boys equitably, promotion of women empowerment, legal and institutional framework to hinder gender discrimination on inheritance and labor market participation should be instituted. 


\section{REFERENCES}

[1] S. Singh, T.Gaurav and P. C. Gupta, A case study on empowerment of rural women through micro entrepreneurship development. IOSR Journal of Business and Management, 9(6) 2013, 123-126.

[2] Human Development Report, International cooperation at a crossroads: aid, trade and security in an unequal world. New York: UNDP, 2005).

[3] INSTRAW progress report, www.un.instrw.org/en/images/stores/Beijing/institutionalmechanisms.pdf 2007.

[4] D. Azuh , F. Oluyemi and L. Ajayi, Socio-cultural factors of gender roles in women's healthcare utilization in Southwest Nigeria. Open Journal of Social sciences, 3, 2015, 105-117.

[5] E., Katz, and J. Chamorro, Gender, land rights, and the household economy in rural Nicaragua and Honduras, Paper presented at the Annual Conf. of the Latin American and Caribbean Economics Association, Puebla, Mexico, 2003.

[6] E., Reed, A. Raj, E. Miller and J. G. Silverman, Losing the gender in gender. Violence against women, $16,2010,348-354$.

[7] United Nations, The United Nations development agenda: development for all, (New York: United Nations, 2007).

[8] Dyson, Tim and Mick Moore, On kinship structure, female autonomy, and demographic behavior in India, Population and Development Review, 9(1), 1983, 35-60.

[9] O. Fasuba, Vacancy: tough women only. (Lagos: The Punch Press 2000).

[10] Yomi, M.K., Women: the disadvantaged specie. (Ibadan: Third World Information Services Publishers 2007).

[11] N. Sadik, Integration of women in population and development programmes, ESCAP, Asia-Pacific Population Journal, 1(3), 1986, 3-59.

[12] Curtin, Leslie B. Status of women: a comparative analysis of twenty developing countries (Washington, D.C.: Population Reference Bureau, Reports on World Fertility Survey, 1982).

[13] National Population Commission, Gender and sustainable development (Abuja: NPC, 2001).

[14] Africa Human Development Report, Accelerating gender equality and women's empowerment in Africa (New York: UNDP, 2016).

[15] M. O. Akintayo, J.E. Oghenekohwo, Developing adult education and community development: NewParadigms (Ibadan: Educational Research and Study Group, 2004).

[16] M. P. Todaro and S. C. Smith, Economic development. (England: Pearson Education Limited 2009).

[17] M. L. Jhingan, The economics of development and planning. (Delhi: Vrinda Publications (p) Ltd, 2011).

[18] Ritzer, G. Contemporary sociological theory and its classical roots: the basic. (New York: McGraw-Hill, 2003).

[19] Parpart, J., Connelly, M. and Barriteu, V. Theoretical perspectives on gender and development. (Canada: International Development Research Centre, 2000).

[20] H. Reeves and S.Baden, Gender and development: concepts and definitions. Prepared for the Department for International Development (DFID). (Brighton, UK: BRIDGE, Institute of Development Studies, 2000).

[21] Kaan tasli, A Conceptual Framework for Gender and Development Studies: From Welfare to Empowerment. Österreichische Forschungsstiftung für Entwicklungshilfe (ÖFSE), 2007.

[22] S. Williams, J. Seed \& A. Mwau, Oxfam gender training manual. (Oxford: Oxfam, 1994).

[23] Human Development Report, Work for human development. (New York: UNDP, 2015). 